\title{
Article/Artigo
}

\section{American tripanosomiasis: a study on the prevalence of Trypanosoma cruzi and Trypanosoma cruzi-like organisms in wild rodents in San Luis province, Argentina}

\author{
Tripanosomiasis americana: um estudo sobre a prevalência do Trypanosoma cruzie Trypanosoma \\ cruzi-like em roedores silvestres da provincia de San Luis, Argentina
}

\author{
Ana María Brigada ${ }^{1,2}$, Roberto Doña ${ }^{2,3}$, Enrique Caviedes-Vidal ${ }^{1,2,4}$, Edgardo Moretti ${ }^{5}$ and Beatriz Basso ${ }^{5,6}$
}

\begin{abstract}
Introduction: Chagas disease is caused by Trypanosoma cruzi. Wild and perianthropic mammals maintain the infection/transmission cycle, both in their natural habitat and in the peridomestic area. The aim of this paper was to present the results from a study on wild rodents in the central and northern regions of San Luis province, Argentina, in order to evaluate the prevalence of this infection. Methods: Sherman traps were set up in capture areas located between latitudes $32^{\circ}$ and $33^{\circ} \mathrm{S}$, and longitudes $65^{\circ}$ and $66^{\circ} \mathrm{W}$. The captured rodents were taxonomically identified and hemoflagellates were isolated. Morphological, biometric and molecular studies and in vitro cultures were performed. Infection of laboratory animals and histological examination of the cardiac muscle and inoculation area were also carried out. Parasites were detected in circulating blood in Calomys musculinus, Graomys griseoflavus, Phyllotis darwini and Akodon molinae. The parasites were identified using biological criteria. Molecular PCR studies were performed on some isolates, which confirmed the characterization of these hemoflagellates as Trypanosoma cruzi. Results and Conclusions: Forty-four percent of the 25 isolates were identified as Trypanosoma cruzi, and the remaining 56\% as Trypanosoma cruzi-like. These findings provide evidence that wild rats infected with Trypanosoma cruzi and Trypanosoma cruzi-like organisms are important in areas of low endemicity.
\end{abstract}

Key-words: American trypanosomiasis. Trypanosoma cruzi. Reservoirs. Wild rodents. Chagas disease.

\section{RESUMO \\ Introdução: A doença de Chagas é causada pelo Trypanosoma cruzi e os mamíferos periantrópicos e silvestres mantêm o ciclo de infecção/transmissão, tanto no ambiente natural, como no peridomicílio. O objetivo deste trabalho foi mostrar os resultados de um estudo de roedores silvestres do centro e norte da Província de San Luis, Argentina, para avaliar a prevalência da infecção.Métodos: Estabeleceram-se lugares de caça com armadilhas tipo Sherman entre os $32^{\circ}-33^{\circ}$ de latitude $S$ e $65^{\circ}$ - 66 ${ }^{\circ}$ de longitude W. Identificou-se taxonomicamente os roedores, isolou-se os hemoflagelados e fizeram-se estudos morfológicos, biométricos, moleculares, cultivo in vitro, infecção a animais de laboratório, histologia de músculo cardíaco e de zona de inoculação. Observou-se parasitas em sangue circulante: Calomys musculinus, Graomys griseoflavus, Phyllotis darwini e Akodon molinae. Aidentificação dos parasitas foi feita utilizando critérios biológicos e, em alguns, realizou estudos moleculares por PCR que confirmaram a caracterização desses hemoflagelados como Trypanosoma cruzi. Resultados e Conclusões: Dos 25 isolados, 44\% foram identificados como Trypanosoma cruzi e 56\% como Trypanosoma cruzi like. Este achado nos induz a considerar a importância dos ratos do mato infectados com Trypanosoma cruzi y Trypanosoma cruzi like, em área de baixa endemicidade.}

Palavras-chaves: Tripanosomiasis americana. Tripanosoma cruzi. Reservatório. Roedores silvestres. Doença de Chagas.

1.Departamento de Bioquímica y Ciencias Biológicas, Facultad de Química, Bioquímica y Farmacia, Universidad Nacional de San Luis, San Luis, Argentina. 2. Laboratorio de Biología "Prof E. Caviedes Codelia”, Facultad de Ciencias Humanas, Universidad Nacional de San Luis, San Luis, Argentina. 3. Área de Psicobiología, Facultad de Ciencias Humanas, Universidad Nacional de San Luis, San Luis, Argentina. 4. Instituto Multidisciplinario de Investigaciones Biológicas de San Luis (IMIBIO-SL) CONICET, San Luis, Argentina. 5. Servicio Nacional del Chagas, Córdoba, Argentina. 6. Facultad e Medicina. Universidad Nacional de Córdoba, Córdoba, Argentina. Address to: Dra. Ana Maria Brigada. Depart. de Bioquímica y Ciencias Biológicas, Facultad de Química, Bioquímica y Farmacia, Universidad Nacional de San Luis, San Luis, Argentina, Chacabuco 917, 5700 San Luis, Argentina.

Tel: $54265242-4027$ int 120

e-mail: abrigad@unsl.edu.ar;ana.brigada@gmail.com

Received in 02/12/2008

Accepted in 16/03/2010

\section{INTRODUCTION}

Chagas disease is widespread in Latin America and is caused by the protozoan parasite Trypanosoma cruzi. Hematophagous Triatominae (Hemiptera: Reduviidae) insects are the major vector of the disease. Wild and perianthropic mammals maintain the infection/transmission cycle in their natural habitat as well as in the peridomestic area ${ }^{1,2}$.

Infection by trypanosomes depends mainly on the convergence of a given time and place, the etiological agent, the vector insect and the host animal, which are the links that comprise the wild cycle of this zoonosis. The increasing interaction between man and habitats of wild fauna favors the developmental cycle of infection, thus transmitting the parasitosis to the human environment.

Chagas disease is one of the main health problems in Latin America. However, its control is complex since the parasite can survive in the bloodstream of different vertebrate hosts and Triatominae vectors ${ }^{3-5}$.

The role of wild animals as reservoirs and the flow of trypanosomes across different habitats heighten the alert regarding the epidemic implications of this disease, and this directly affects the quality of life of the Latin

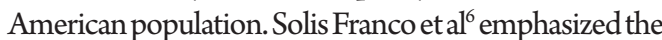
importance of rodents in maintaining the wild cycle of this disease. Trypanosoma cruzi has been reported to be present in more than 200 mammal species $^{7-10}$, including some rodents dwelling in Argentina, such as Calomys musculinus ${ }^{11}$, Akodondolores ${ }^{12}$, Calomys laucha ${ }^{13}$, Phyllotis griseoflavus $^{14}$ and Octodontomys gliroides ${ }^{15}$.

The aim of this work was to investigate whether wild rodents in the central and northern regions of San Luis province, Argentina (an area of low endemicity for Chagas disease) were infected with Trypanosoma cruzi, along with the prevalence of this infection. Statistical data provided by the San Luis Health Ministry show that the prevalence of this infection in blood banks in this province has reached around $7 \%$ over the last few years. 


\section{METHODS}

\section{Study area}

- Sample areas with phytogeographical characteristics representing typical vegetation formations in San Luis province were selected ${ }^{16}$.

- Lomas Blancas $\left(32.72^{\circ} \mathrm{S} ; 66.73^{\circ} \mathrm{W}\right)$; vegetation formation: ecotone of Aspidosperma quebracho-blanco and Prosopis flexuosa forest and the Monte desert.

- Mesilla del Cura (32.44 S; 65.78 W) and La Bajada (33.01 $\mathrm{S}$; $\left.66.01^{\circ} \mathrm{W}\right)$; vegetation formation: montane grasslands and forest.

- La Botija (32.24 $\left.\mathrm{S} ; 66.58^{\circ} \mathrm{S}\right)$ and Daniel Donovan (33.33우 $\left.66.22^{\circ} \mathrm{W}\right)$; vegetation formation: Aspidosperma quebracho-blanco and Prosopis flexuosa forest.

- Beazley $\left(33.75^{\circ} \mathrm{S} ; 66.64^{\circ} \mathrm{W}\right)$; vegetation formation: low forest of Prosopis flexuosa, Larrea divaricata and Geoffroea decorticans.

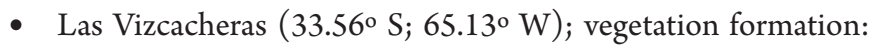
ecotone of Aspidosperma quebracho-blanco and Prosopis flexuosa forest - Prosopis caldenia forest.

\section{Capture system}

In each sampling area, a capture system was established with Sherman traps bated with ground oat grains. These traps were maintained for three to six nights and were checked daily in the early morning. Samples were collected over a two-year period. After capture, the animals were immediately transported to the laboratory, for laboratory assays to be started.

\section{Laboratory work}

Morphological and biometric studies on the hemoflagellate protozoa: blood was taken from all of the captured rodents, and parasites were detected using the Woo technique ${ }^{17}$. Blood smears were stained with Giemsa (1:10) after fixing with methanol. The morphology of the parasites was observed using an optical microscope (Olympus BX50). Biometric assessments was performed on microphotographs obtained using a Sony video camera and the capture X, AIMS Video Highway X-treme software. The parasites were measured against a standardized scale, and the following measurements were obtained: FL: flagellum length; BL: body length; TL: total length; PN: distance from the posterior end of the body to the center of the nucleus; AN: distance from the anterior end of the body to the center of the nucleus; and PN/AN: mean nuclear index

\section{Cultures}

Blood was cultured in Senekjie's culture medium ${ }^{18}$ and maintained at $28^{\circ} \mathrm{C}$. The blood cultures were then examined over a period of up to 30 days, starting on the fifth day after culturing.

\section{Infection of laboratory animals}

Three to ten-day-old Balb/c albino mice $(n=300)$ were infected subcutaneously with blood taken from wild animals, containing between 3 and $5 \times 10^{6}$ trypanosomes $/ \mathrm{ml}$. Parasitemia was controlled starting from the seventh day after inoculation.

\section{Histological studies}

A search for amastigotes was carried out in histological heart sections and in the inoculation area, stained with hematoxylin-eosin.

\section{Polymerase chain reaction}

The polymerase chain reaction was carried out on trypanosomes isolated from Akodon molinae was carried out. These parasites were analyzed by amplifying the DNA of the parasite using oligonucleotides \# 121 and \# 122, in accordance with the technique described by Winckler et a ${ }^{19}$. These oligonucleotides were designed to amplify $330 \mathrm{bp}$ DNA fragments from regions of the parasite kinetoplastid minicircles (k-DNA).

Oligonucleotide

\# 121 ( $5^{\prime \prime}$ a $\left.3^{\prime}\right)$

\# 122 ( $5^{\prime \prime}$ a $3^{\prime}$

Briefly, DNA was extracted from the blood of the infected animals, then treated with a lysis buffer (SDS 1\%; Tris-HCl 10mM, $\mathrm{pH} 8$; EDTA 100mM) using the conventional phenol-chloroform technique, and the final precipitate was resuspended in bidistilled sterile water and stored at $-20^{\circ} \mathrm{C}$. The reaction was carried out in a final volume of $100 \mu \mathrm{l}$, by applying $10 \mu \mathrm{l}$ of reaction buffer $10 \mathrm{X}$ for the Taq polymerase (Tris- $\mathrm{HCl} 100 \mathrm{mM}, \mathrm{pH} 8.3 ; \mathrm{KCl} 500 \mathrm{mM}$ ); $12 \mu \mathrm{l}$ of $\mathrm{MgCl}_{2} 25 \mathrm{mM} ; 10 \mu \mathrm{l}$ of a mixture of dNTPs (10mM of each one); and $10 \mu \mathrm{l}$ of each Trypanosoma cruzi-specific primer for amplifying and differentiating Trypanosoma cruzi kDNA. Thirty-seven cycles were performed, at between $68^{\circ} \mathrm{C}$ and $94^{\circ} \mathrm{C}$.

\section{Statistical analysis}

The parasitemia levels of the different species were contrasted using the percentage of infected animals in each species, and each sampled location, by applying the Wilcoxon matched pairs test ${ }^{20}$. Only the species that were captured in more than five sampling locations were used.

\section{RESULTS}

Parasites were detected in circulating blood in four of the seven species analyzed: Calomys musculinus $(\mathrm{Cm})$ 6.9\% (percentage of infected individuals), 8/115 (infected individuals/total captured individuals); Graomys griseoflavus (Gg) 13.6\%, 9/66; Phyllotis darwini $(P d)$ 18.7\%, 3/16; Akodon molinae (Am) 10.2\%, 5/49. No significant differences in infection prevalence according to study area were observed.

No circulating parasites were detected in Calomys venustus $(\mathrm{n}=7)$, Calomys laucha $(\mathrm{n}=5)$ and Akodon sp $(\mathrm{n}=2)$.

The criteria proposed by Barreto ${ }^{21}$ were used for parasite identification. Molecular biology techniques were also performed on some isolates.

\section{Morphological studies}

Figure 1 shows the parasites in blood smears from the infected animals. The parasites are $\mathrm{C}$ or $\mathrm{S}$-shaped with an undulating membrane, short flagellum, prominent subterminal kinetoplast and well-defined nucleus.

\section{Biometric studies}

Table 1 shows the mean values from the biometric studies carried out on the parasites analyzed.

\section{Parasite culture}

Animal blood cultured in Senekjie's culture medium exhibited multiplication of parasites and the characteristic formation of free epimastigotes, starting from the sixth day of culturing (data not shown). 


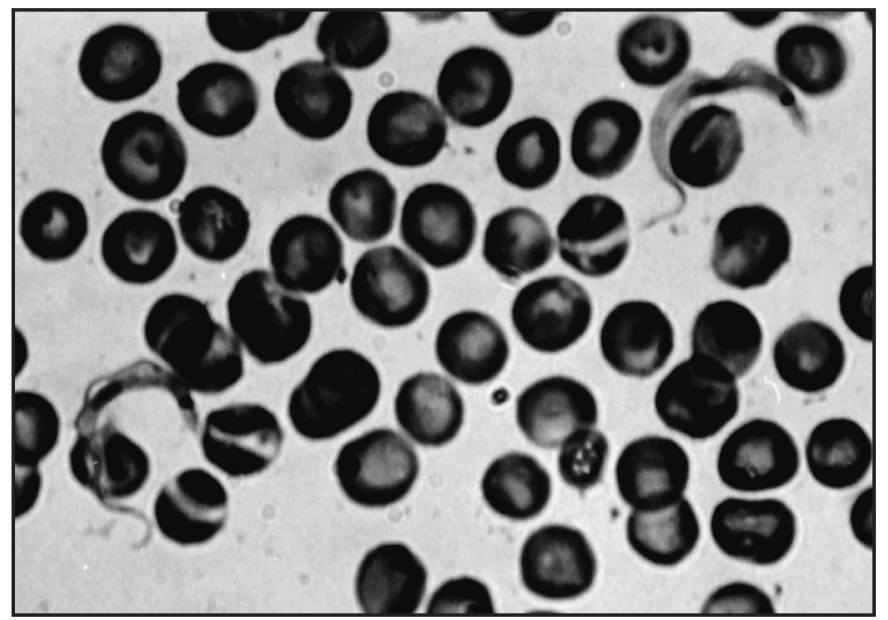

FIGURE 1 - Microphotograph of isolated tripomastigotes (100X) isolated from Calomys musculinus. Blood smear stained with Giemsa.

\begin{tabular}{|c|c|c|c|c|c|c|}
\hline Species & $\operatorname{FL}(\mu)^{\mathrm{a}}$ & $\operatorname{LC}(\mu)^{b}$ & $\mathrm{TL}(\mu)^{\mathrm{c}}$ & $\operatorname{PN}(\mu)^{d}$ & $\operatorname{AN}(\mu)^{e}$ & $\mathrm{PN} / \mathrm{AN}^{\mathrm{f}}$ \\
\hline \multicolumn{7}{|l|}{$\mathrm{Cm}$} \\
\hline$(\mathrm{n}=138)$ & $5.01 \pm 0.37$ & $20.03 \pm 2.54$ & $25.04 \pm 2.51$ & $9.35 \pm 0.95$ & $10.68 \pm 1.74$ & $0.85 \pm 0.20$ \\
\hline \multicolumn{7}{|l|}{$\mathrm{Pd}$} \\
\hline$(\mathrm{n}=30)$ & $5.10 \pm 1.0$ & $18.38 \pm 2.00$ & $23.60 \pm 1.50$ & $8.82 \pm 1.40$ & $9.57 \pm 1.50$ & $0.94 \pm 0.20$ \\
\hline \multicolumn{7}{|l|}{$\mathrm{Am}$} \\
\hline$(n=36)$ & $5.64 \pm 1.55$ & $19.80 \pm 1.10$ & $25.52 \pm 0.38$ & $10.31 \pm 0.32$ & $9.44 \pm 0.69$ & $1.10 \pm 0.05$ \\
\hline \multicolumn{7}{|l|}{$\mathrm{Gg}$} \\
\hline$(\mathrm{n}=30)$ & $8.21 \pm 2.00$ & $18.51 \pm 2.20$ & $26.58 \pm 2.70$ & $9.68 \pm 1.00$ & $8.80 \pm 1.50$ & $1.10 \pm 0.20$ \\
\hline
\end{tabular}

Measurements expressed in micrometers \pm 1 standard deviation. ${ }^{a}$ flagellum length, ${ }^{\mathrm{b}}$ body length, ${ }^{\mathrm{c}}$ total length, ${ }^{\mathrm{d}}$ distance from the posterior end of body to the center of the nucleus, ${ }^{e}$ distance from the anterior end of body to the center of the nucleus, $\mathrm{f}_{\text {average nuclear index. }}$

\section{Inoculation in laboratory animals}

On the seventh day, circulating parasites were observed and the morphology was similar to that of Trypanosoma cruzi. Moreover, the biometric measurements matched Barreto's criteria established for this species.

\section{Histological studies}

The presence of amastigote pseudocysts was observed through histological examination of heart tissue sections (Figure 2A). Figure 2B shows the various stages of the parasites in Giemsa-stained inoculation areas.

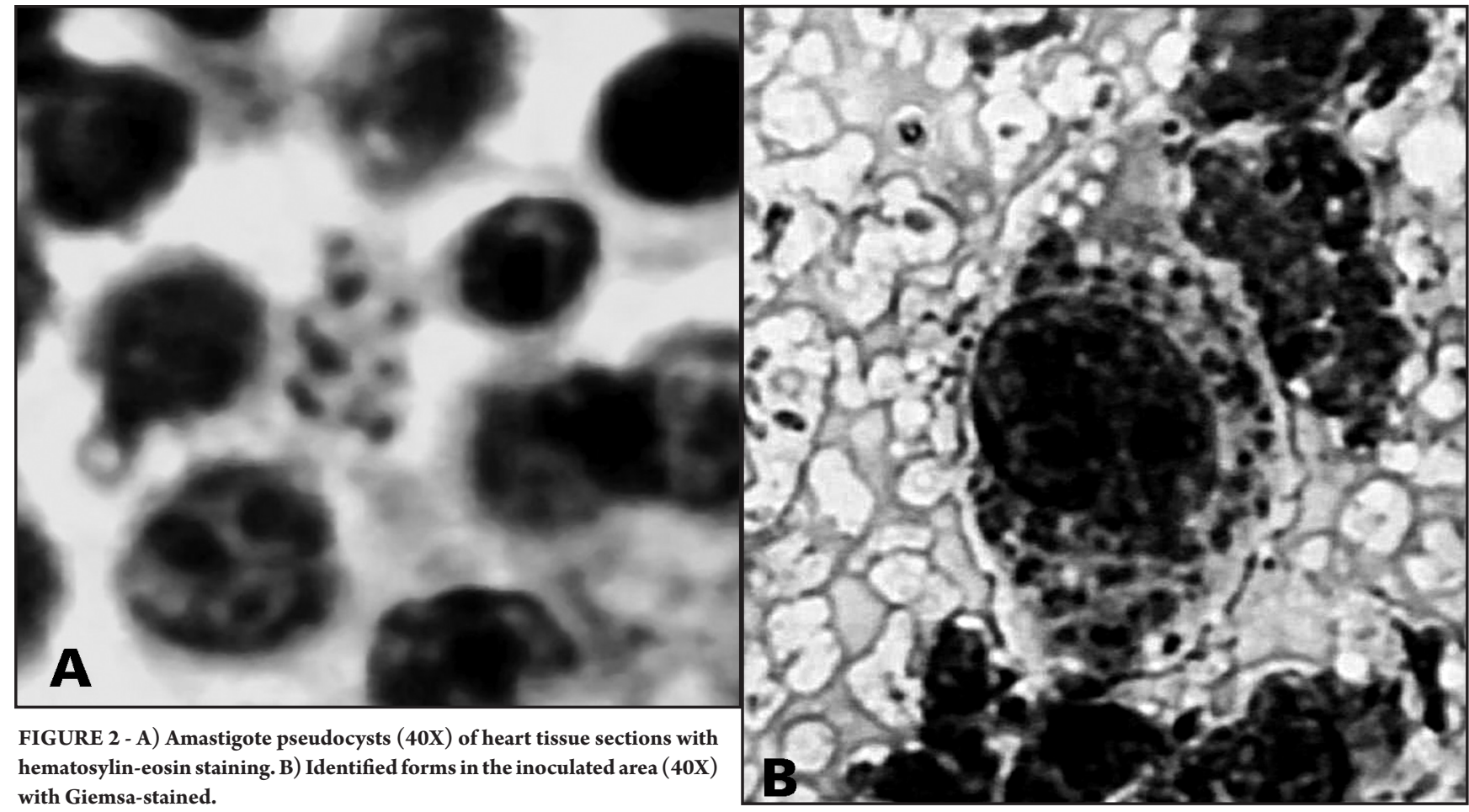




\section{PCR analysis}

DNA isolated from parasites in Akodon molinae was used for the PCR reaction using specific primers for Trypanosoma cruzi. Trypanosoma cruzi Tulahuen DNA was used as a positive control. DNA samples of parasites isolated from Akodon molinae showed fragments of sizes similar to the controls (330bp) (Figure 3).

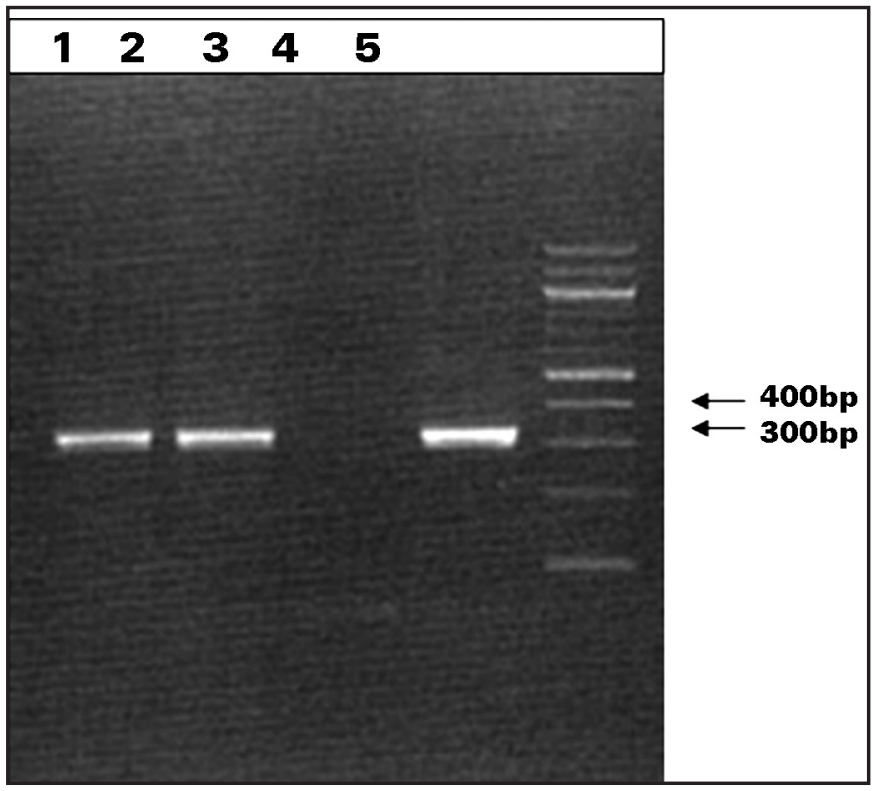

FIGURE 3 - Lane 1 and 2 show the 330-bp fragment amplified for the isolated sample of Akodon molinae. Lane 3 shows the negative control. Lane 4 shows the positive control whereas. Lane 5 shows the molecular weight markers.

\section{DISCUSSION}

Several authors have studied rodents as hosts for trypanosomes ${ }^{10-12,22-24}$. Most of these studies had the aim of describing species as trypanosome reservoirs. The present study introduces a horizontal analysis in which various rodent species (Calomys musculinus, Graomys griseoflavus, Phyllotis darwini and Akodon molinae) were found infected with Trypanosoma cruzi or Trypanosoma cruzi-like trypanosomes. These results support the notion that micromammals in general and rodents in particular are important as trypanosome reservoirs.

In accordance with the postulates of Barretto ${ }^{21}$, the first factor considered in identifying the trypanosomes was their morphological characterization. This study showed that the morphology of the parasites isolated was similar to Trypanosoma cruzi. In fact, the arrangement of the nuclei and the kinetoplasts of the parasites detected in the animals captured in the Lomas Blancas, Mesilla del Cura, La Bajada, Daniel Donovan and Las Vizcacheras areas matched the morphology of the two blood types described for Trypanosoma cruzi: a very mobile, thin shape with an elongated nucleus, a subterminal kinetoplast and short flagellum; and a thick, slow-moving shape with an oval nucleus and a long, free flagellum ${ }^{21-25}$.

The second parameter was the biometric measurements. In a recent study, Martins et $\mathrm{al}^{26}$ suggested that morphometry is an important method for biological characterization of Trypanosoma cruzi. Biometric measurements performed on the blood forms of naturally infected animals confirmed that the parasites isolated from 11 of them were within the range of the mean nuclear index (NA/NP) defined for Trypanosoma cruzi $i^{8}$. Moreover, the biometric measurements performed on the trypanosomes obtained from the circulating blood of the Balb/c mice inoculated with blood from field animals showed similar values to those of the respective wild strain.

One interesting observation was that the mortality rate among the laboratory $\mathrm{Balb} / \mathrm{c}$ mice inoculated with wild strains was very high during the acute phase of the infection. In addition, amastigote forms found in histological sections of cardiac tissue and in the macrophages of the inoculation area of the experimentally infected Balb/c mice were characteristic of the developmental cycle of Trypanosoma cruzi and were one of the fundamental parameters for characterizing the strains ${ }^{4,8}$. The fact that no amastigotes were observed in the naturally infected wild animals was in agreement with previous findings ${ }^{11-13}$. According to Deane $\mathrm{e}^{23}$, the lack of amastigotes may be due to analyzing the wild animals during the chronic phase of the infection, when the tissue forms are scarce. In the areas where the infected wild rodents were captured, no wild triatomines (which would potentially be responsible for wild transmission) were found.

An additional xenodiagnosis performed on some of the experimentally infected wild mice revealed the characteristic metacyclic epimastigote and trypomastigote forms that were observed in the vector (data not shown).

The molecular biological studies performed on the trypanosome isolates from Akodon molinae provided additional data that supported the identification of these hemoflagellates as Trypanosoma cruzi.

Together, the results from this study confirmed that 11 (44\%) of the 25 isolates were Trypanosoma cruzi. The other 14 (56\%) were classified only as Trypanosoma cruzi-like, in terms of morphology, biometric measurements, similar reservoir use and capture areas, since not all of the studies were performed on them. The presence of Trypanosoma lewisi was discarded because no blood splitting due to this protozoon was observed.

Finally, it is important to state that to our knowledge, this is the first time that the prevalence of Trypanosoma cruzi and Trypanosoma cruzi-like organisms has been reported in wild rodents of seven different populations from the Midwest region of Argentina, inhabiting different phytogeographical regions in an area where $7 \%$ of the population is serologically positive for Chagas disease. Moreover, these results confirm that this parasite is widespread in the wild environment, in spite of preventive fumigation efforts, and it maintains an independent cycle that might be influenced by factors that are still unknown and which could influence the human population's health.

\section{ACKNOWLEDGMENTS}

The authors dedicate this manuscript to Dr. Enrique Caviedes Codelia on his $10^{\text {th }}$ death anniversary and for his important participation in this research. The authors would also like to thank Mariana Jofre, Antonio Mangione and María Eugenia Ciminari for collaborating in the field study, Adriana Garcia and Noemí Rodríguez for their commitment to laboratory work, Fabricio Cid for his support and Mrs Maria Fernanda Garstein for English editing.

\section{CONFLICT OF INTEREST}

The authors declare that there is no conflict of interest. 


\section{FINANCIAL SUPPORT}

Universidad Nacional de San Luis, Argentina.

\section{REFERENCES}

1. Carcavallo R. Aspects of the epidemiology of Chagas disease in Venezuela and Argentina. New Approaches in American Trypanosomiasis Research. PAHO; 1975. p.318-347.

2. Pessoa SB. Hospedeiros vertebrados (nao humanos) do Trypanosoma cruzi. Goiana Medical 1958; 4: 83.

3. Chagas C. Nova tripanosomiase humana.Estudos sobre a morfolojia e o ciclo evolutivo do Schizotrypanum cruzi, ng, nSp, ajente etiológico de nova entidade morbida do homem. Mem do Inst Oswaldo Cruz 1909; 1:159-218.

4. Días JCP. Chagas disease-American trypanosomiasisits impact on transfusion and clinical medicine. In: Wendel S, Brener Z, Camargo MG, Rassi A. editor Brazil,1992.

5. Guzman-Martin E, Zavala-Castro JE, Acosta-Viana KY, Rosado-Barrera ME. Importancia de la caracterización de cepas de Trypanosoma cruzi. Rev Biomedica 1999; 10:177-184.

6. Solís-Franco R, Romo-Zapata JA, Martínez-Ibarra JA. Wild Reservoirs Infected by Trypanosoma cruzi in the Ecological Park "El Zapotal”, Tuxtla Gutiérrez, Chiapas, México. Memorias do Instituto Oswaldo Cruz 1997; 92: 163-164.

7. Brener Z. Biology of Trypanosoma cruzi. Annales Revista Microbiologia 1973;27: 347-382.

8. Ferriolli F, Barretto MP, Carvalheiro JR. Estudos sobre reservatorios e vectores silvestres do Trypanosoma cruzi. XXIV. Variação dos dados biometricos obtidos em amostras do T. cruzi isolados de casos humanos da Doenca de Chagas. Rev Soc Bras Med Trop 1968; I:2.

9. Hoare CA. Morphological and taxonomic studies on mammalian trypanosomes. X Revision of the Systematies. Journal Protozoology 1964; 11: 200-207.

10. Hoare CA. The trypanosomes of mammals. AZoological Monograph. Blackwell Scientific Publications, Oxford and Edinburg; 1972.

11. Basso B, Eraso AJ, Moretti ER, Albesa I, Kravetz F. Infección natural de Calomys musculinus (Rodentia: Cricetidae) por Trypanosoma cruzi. Asociación Argentina de Microbiología 1977; 9: 11-16.

12. Basso B, Moretti ER, Albesa I, Eraso AJ, Kravetz F, Dalessandro A. Infección natural de Akodon dolores Thomas 1916, (Rodentia: Cricetidae) por el Trypanosoma cruzi. Rev Inst Med Trop São Paulo1982; 24: 21-26.

13. Moretti ER, Basso B, Albesa I, Eraso AJ, Kravetz FO. Infección natural de Calomys laucha por Trypanosoma cruzi. Medicina 1980; 40 (supl 1): 182-186.

14. Rodríguez LR, Carcavallo R, Massoia EF. Estudios del Phyllotis griseoflavus como reservorio de T. cruzi. Segundas Jornadas de Entomología Argentina; 1960. p.75-83.

15. Schweigmann NJ, Alberti A, Pietrokovsky S, Conti O, Riarte A, Montoya S, Wisnivesky-Colli C. A new host of Trypanosoma cruzi from Jujuy, Argentina: Octodontomys gliroides (Gervais \& D’Orbigny, 1844) (Rodentia, Octodontidae). Mem Inst Oswaldo Cruz 1992; 87: 217

16. Anderson DL, del Aguila J, Bernardon A. Las formaciones vegetales en la provincia de San Luis. Revista Investigaciones Agropecuarias. INTA. Serie 2, Biol Produc Vegetal 1970; VII 3:152-183.

17. Woo PT. The haematocrit centrifuge for the detection of trypanosomes in blood. Cana J Zoology 1969; 47:921-924.

18. Senekjie HA. Biochemical reactions, cultural characteristics and growth requirements of Trypanosoma cruzi. Ame J Trop Med Hygiene 1943; 23:523.

19. Winckler P, Britto C, Pereira JB, Cardoso MA, Oelemann W, Morel CM. Use of a simplified polymerase chain reaction procedure to detect Trypanosoma cruzi in blood samples from chronic chagasic patients in a rural endemic area. Am J Trop Med Hygiene 1994; 51:771-777.

20. Wilcoxon F. Individual comparisons by ranking methods. Biometrica Bulletin $1945 ; 1: 80-83$.

21. Barretto MP. Tripanossomos semelhantes ao Trypanosoma cruzi em animais silvestres esua identificacao com o agente etiológico doenca de Chagas. Rev Inst Med Trop Sao Paulo 1965; 7:305-315.
22. Cortez MR, Pinho A, Cuervo P, Alfaro F, SolanoM, Xavier SCC, D’Andrea PS, Fernandes O, Torrico F, Noireau F, Jansen AM. Trypanosoma cruzi (Kinetoplastida Trypanosomatidae): Ecology of the transmission cycle in the wild enviroment of Andean vallery of Cochabamba, Bolivia. Experim Parasitol 2006; 114:305-313.

23. Deane LM. Animal reservoirs of Trypanosoma cruzi in Brazil. Rev Bras Malariol Doen Trop 1964;16: 27-48.

24. Xavier SC, Vaz VC, D’Andrea PS, Herrera L, Emperaire L, Alves R, Fernández O, Ferreira LF, Jansen AM. Mapping of the distribution of Trypanosoma cruzi infection among small wild mammals in a conservation unit and its sorrounding (Northeast Brazil). Parasitol Internat 2007; 56:119-128.

25. Souza WA. Short Review on the morphology of Trypanosome cruzi: from 1909 to 1999. Mem Inst Oswaldo Cruz 1999; 94(Supl I):17-36.

26. Martins LA, Castaño REP, Gusmao AS, Rosa JA. Morfometría de Tripomastigotas sanguíneos de Tripanosoma cruzi Chagas, 1909 (Kinetoplastidae, Trypanosomatidae). Rev Patol Reg 2008;37:143-150. 